\title{
Bibliography of Dr. Errett Hargrove Callahan Jr.
}

\author{
Otis N. Crandell \\ Centro de Estudos e Pesquisas Arqueológicas. Departamento de Antropologia. Universidade Federal do Paraná. \\ Curitiba, Brazil. Email: otis.crandell@gmail.com
}

\begin{abstract}
:
The following is a bibliography of the works of Errett H. Callahan and works about him. This is has been written to accompany the biography written by Hugo Nami (this issue).
\end{abstract}

Keywords: Errett Callahan; modern knapper; experimental archaeology; bibliography; biography

\section{A brief introduction to the bibliography}

This article is intended to be a comprehensive list of publications by and about Errett Callahan. It was written to accompany the biography written by Hugo Nami which is published in this same issue. Every effort has been made to include all publications by Dr. Callahan and it is presumed that almost all (if not all indeed) have been included. All of his major publications appear in this bibliography. If other publications are later found to be missing, please inform me so that they can be added to the list in some way. Regarding publications about Dr. Callahan, considering his long and illustrious career, and the many people who he trained, worked with, and influenced, it is very likely that there are publications missing from this list. If missing publications are noticed, please inform me of these as well so that they may be added. The bibliography will be made available as an RIS file and EndNote compressed library for easy use in bibliographic software.

\section{Works by Errett Callahan}

Callahan, E.H. 1964, Make your own micropack. Sports Afield, 151(6): 56-104.

Callahan, E.H. 1966, Errett Callahan; Catalog of an exhibition held Sept. 20-Oct. 8, 1966. Larcada Gallery, New York, 6 p.

Callahan, E.H. 1969, Chip your own arrowheads. Bow and Arrow Magazine, 6(6): 24-27.

Callahan, E.H. 1971, Experimental Archaeology 499-E: A sampling (mimeographed). Department of Sociology \& Anthropology, Virginia Commonwealth University, Richmond, VA.

Published by the School of History, Classics and Archaeology, University of Edinburgh ISSN: 2055-0472. URL: http://journals.ed.ac.uk/lithicstudies/ 
Callahan, E.H. 1972, Acheulean handaxes. The APE. Experimental Archeology Newsletter, 1: 20-24.

Callahan, E.H. 1972, Course description. In Experimental Archeology 499-E: A sampling. Newsletter of Experimental Archeology (APE), 1: 3-4.

Callahan, E.H. (Ed.) 1972, Experimental Archaeology Newsletter. Vol. 1. Commonwealth University, Richmond, VA.

Callahan, E.H., (director), 1972, Fluting. film on file at the Piltdown Productions Library, Lynchburg.

Callahan, E.H. 1973, Flint workshop debitage. Newsletter of Experimental Archaeology, 2: 51-63.

Callahan, E.H., (director), 1973, Lithic technology Part I: Percussion biface replication. C \& K Productions \& Virginia Commonwealth University, Richmond, VA. Super 8 mm, colour, magnetic sound. Running time: 18 min.

Callahan, E.H. 1973, Living archeology - Toward a better understanding of the past. Archaeology Magazine, 26: 220.

Callahan, E.H. 1973, The Old Rag Project, a preliminary report. Newsletter of Experimental Archaeology, 2: 64-77.

Callahan, E.H. 1973, The Old Rag Report: A practical guide to living archaeology. Department of Sociology and Anthropology, Virginia Commonwealth University, Richmond, VA, $155 \mathrm{p}$.

Callahan, E.H. 1973, Variability in the early stages of manufacture of Virginia Fluted Points: an experimental study. MS thesis at Catholic University of America, Washington, D.C., $179 \mathrm{p}$.

Callahan, E.H. (Ed.) 1974, The APE. Experimental archaeology papers, Experimental Archaeology Papers (APE) Vol. 3. Department of Sociology and Anthropology, Virginia Commonwealth University, Richmond, 213 p.

Callahan, E.H. 1974, A guide for flintworking: Stages of manufacture. In: Experimental Archaeology Papers (APE) Vol. 3 (Callahan, E.H., Ed.): p. 185-192.

Callahan, E.H. 1974, Some edible and useful plants of Northern Arizona, especially Coconino County. In: Experimental Archaeology Papers (APE) Vol. 3 (Callahan, E.H., Ed.): p. 164-180.

Callahan, E.H. 1974, The Wagner basalt quaries: a preliminary report. In: ___Experimental Archaeology Papers (APE) (Callahan, E.H., Ed.). Experimental Archaeology Papers (APE) Vol. 3, Department of Sociology and Anthropology, Virginia Commonwealth University, Richmond, VA: p. 9-128.

Callahan, E.H. (1975). Flake removal sequence and cultural inference. presented at the Lithic Symposium: Recent Emphasis en Lithic Technology, 40th Annual Meeting, Society for American Archaeology, Dallas.

Callahan, E.H. (1975), The Williamson and flint run fluting traditions, clarified: An experimental study: Part $1:$ Early stages of manufacture. unpublished manuscript.

Callahan, E.H. 1976, Documentation of artifacts, Pamunkey Project phase I. In: The Pamunkey Project Phases I and II (Callahan, E.H., Ed.). Experimental Archaeology 
Papers (APE) Vol. 4, Department of Sociology \& Anthropology, Virginia Commonwealth University, Richmond, VA: p. 178-242.

Callahan, E.H. 1976, Experimental Archeology: Unlocking the Doors of Time. Quarterly Bulletin - Archeological Society of Virginia, 30(3): 154-158.

Callahan, E.H. 1976, Fishing technologies at the Pamunkey site, phase II. In: The Pamunkey Project Phases I and II (Callahan, E.H., Ed.). Experimental Archaeology Papers (APE) Vol. 4, Department of Sociology \& Anthropology, Virginia Commonwealth University, Richmond, VA.

Callahan, E.H. 1976, Lithic technology at the Pamunkey site, phase II. In: The Pamunkey Project Phases I and II (Callahan, E.H., Ed.). Experimental Archaeology Papers (APE) Vol. 4, Dept. of Sociology \& Anthropology, Virginia Commonwealth Univ., Richmond, VA: p. 376-422.

Callahan, E.H. 1976, A lithic workshop symposium. Newsletter of Lithic Technology, 5(1-2): 3-5. URL: https://www.jstor.org/stable/43822612

Callahan, E.H. (Ed.) 1976, The Pamunkey Project Phases I and II, Experimental Archaeology Papers (APE) Vol. 4. Department of Sociology and Anthropology, Virginia Commonwealth University, Richmond, VA, 456 p.

Callahan, E.H. 1976, The Pamunkey Project Phases I and II. In: The Pamunkey Project Phases I and II (Callahan, E.H., Ed.). Experimental Archaeology Papers (APE) Vol. 4, Dept. of Sociology \& Anthropology, Virginia Commonwealth Univ., Richmond, VA.

Callahan, E.H. 1976, Shelter Construction at the Pamunkey Site. In: The Pamunkey Project Phases I and II (Callahan, E.H., Ed.). Experimental Archaeology Papers (APE) Vol. 4, Dept. of Sociology \& Anthropology, Virginia Commonwealth Univ., Richmond, VA: p. 160-177.

Callahan, E.H. 1978, Craftsman.... J.B. Sollberger. Flintknappers' Exchange, 1(1): 12-17.

Callahan, E.H. 1978, Craftsman.... Jeff Flenniken. Flintknappers' Exchange, 1(3): 16-24.

Callahan, E.H. 1978, Craftsman.... Robson Bonnichsen. Flintknappers' Exchange, 1(2): 1624.

Callahan, E.H. 1978, Editorial. Flintknappers' Exchange, 1(1): 2-4.

Callahan, E.H. 1978, Editorial. Flintknappers' Exchange, 1(2): 2-3.

Callahan, E.H. 1978, The Ginsburg Experience: A Mammoth Task". Flintknappers' Exchange, 1(2): 31-32.

Callahan, E.H. 1978, On Identifying and Documenting Replicas. Flintknappers' Exchange, 1(1): 10-11.

Callahan, E.H. 1978, Reply Jacqueline Nichols' "Problems / solutions" Flintknappers' Exchange, 1(3): 28.

Callahan, E.H. 1978, Review of "Paleo Points: An Illustrated Chronology of Projectile Points" by George Bradford. Flintknappers' Exchange, 1(2): 27.

Callahan, E.H. 1978, Synthetic Billet Material. Flintknappers' Exchange, 1(1): 9-10.

Callahan, E.H. 1979, The basics of biface knapping in the Eastern Fluted Point tradition. A manual for flintknappers and lithic analysts. Archaeology of Eastern North America, 7(1): 1-180. 
Callahan, E.H. 1979, Comments on Patten's Analysis of the Clovis from Clovis [FE2[2]:5-8]. Flintknapper's Exchange, 2(3): 17.

Callahan, E.H. 1979, Craftsman... Don Crabtree. Flintknappers' Exchange, 2(2): 8-13.

Callahan, E.H. 1979, Craftsman... Don Crabtree. Flintknappers' Exchange, 2(3): 22-27.

Callahan, E.H. 1979, Editorial. Flintknappers' Exchange, 2(1): 1-3.

Callahan, E.H. 1979, Editor's comment (to "Minimum Effort Strategies in Lithic Reduction" Patterson, same issue). Flintknappers' Exchange, 2(1): 12-13.

Callahan, E.H. 1979, From the Editors. Flintknappers' Exchange, 2(3): 1.

Callahan, E.H. 1979, Interview with Don Crabtree on December 28, 1978. Flintknappers' Exchange, 2(1): 29-33.

Callahan, E.H. 1979, Review of "The Art of Flint Knapping" by D.C. Waldorf. Flintknappers' Exchange, 2(3): 11.

Callahan, E.H. \& Nichols, J. 1979, The Wyoming Knap-in. Flintknappers' Exchange 2(2): 1.

Knudson, R., Callahan, E.H. \& Nichols, J. 1979, Craftsman.... Don Crabtree. Flintknappers' Exchange, 2(1): 27-35.

Callahan, E.H. 1980, Craftsman... Bo Madsen. Flintknappers' Exchange, 3(3): 23-25.

Callahan, E.H. 1980, Craftsman.... Bo Madsen. Flintknappers' Exchange, 3(2): 20-24.

Callahan, E.H. 1980, Editorial Note. Flintknappers' Exchange, 3(3): 1.

Callahan, E.H. 1980, International Work Seminar I: A pilot project in flintknapping workshops. Flintknappers' Exchange, 3(1): 4-5.

Callahan, E.H. 1980, Interview with Gene Titmus. Flintknappers' Exchange, 3(1): 21, 23-25.

Callahan, E.H. 1980, Reply to "Soft stone hammer percussion" (Patten, same issue). Flintknappers' Exchange, 3(1): 17-18.

Callahan, E.H. 1980, Spatial Organization of the Work Areas of Three Contenporary Flintknappers. Bulletin - Archeological Society of Virginia, 35(2): 101-108.

Callahan, E.H. 1980, A special editorial. Flintknappers' Exchange, 3(2): 24.

Callahan, E.H. 1980, Two new books on experimental archaeology. Flintknappers' Exchange, $3(2): 6$.

Flenniken, J., Callahan, E.H. \& Crabtree, D. 1980, Craftsman.... Gene Titmus. Flintknappers' Exchange, 3(1): 19-25.

Callahan, E.H. 1981, Comment on "Fineness Syndrome" (Patterson, FE3(2)). Flintknapper's Exchange, 4(1): 12.

Callahan, E.H. 1981, Danish Dagger A-10198. Flintknappers' Exchange, 4(2): 11-14.

Callahan, E.H. (1981). The Maturation of Experimental Archaeology: A Critical View. presented at the Experimental Archaeology: The Old and the New. Second International Work Seminar in Lithic Technology, 6 August 1981, Lejre Research Center, Lejre, Denmark.

Callahan, E.H. (1981). The new experimental archaeology: a case study. presented at the Prehistoric Institute, University of Arhus, 17 November 1981, Moesgård, Denmark. 
Callahan, E.H. 1981, Pamunkey Housebuilding: An Experimental Study of Late Woodland Construction Technology in the Powhatan Confederacy. Unpublished Ph.D. dissertation thesis at Catholic University of America, Washington, D.C., 538 p.

Callahan, E.H. 1982, An interview with flintknapper Jacques Pelegrin. Contract Abstracts, 3(1): $62-70$.

Callahan, E.H. 1982, The second international work seminar in lithic technology (Lejre, August 1-9 1981). Flintknappers' Exchange, 5(1).

Callahan, E.H. 1982, The second international work seminar in lithic technology (Lejre, August 1-9 1981)[reprint from Flintknappers' Exchange, 5(1)]. Bulletin of Experimental Archaeology, 3: 12-16.

Callahan, E.H. 1984, The 1983 Flintknapping Field School in Oregon. Lithic Technology, 13(1): 30-31. doi:10.1080/01977261.1984.11720846

Callahan, E.H. 1984, I hate to bicker, but...: A study of microblade cores with obtuse platform angles. Lithic Technology, 13(3): 84-97. doi:10.1080/01977261.1984.11720855

Callahan, E.H. 1984, A Successful Test Model of the Type IV Danish Dagger. Flintknapping Digest, 1(10): 2-6.

Callahan, E.H. 1984-1995, various comments and letters on flintknapping. Flintknapping Digest.

Callahan, E.H. 1985, Experiments with Danish Mesolithic Microblade Technology. Journal of Danish Archaeology, 4(1): 23-39. doi:10.1080/0108464x.1985.10589933

Callahan, E.H. 1985, The Fintknapping Industry of Eben-Emael. Quarterly Bulletin Archeological Society of Virginia, 40(2-3): 108-111.

Callahan, E.H. 1985, Flintknapping Flash Cards. Pressure Flaking of Flakes. Piltdown Productions, Lynchburg, 20 cards (double sided) p.

Callahan, E.H. 1985, The St. Mary's longhouse experiment: the first season. Quarterly Bulletin - Archeological Society of Virginia, 40: 12-40.

Callahan, E.H. 1986, A Reply to Edwards. Quarterly Bulletin - Archeological Society of Virginia, 41(2): 108-112.

Callahan, E.H. 1986, A Reply to Thurman. Quarterly Bulletin - Archeological Society of Virginia, 41(2): 97-105.

Callahan, E.H. 1986, Report on the 1986 Flintknapping Technology Field School Course at Manitoga. Lithic Technology, 15(3): 112-113. doi:10.1080/01977261.1986.11754492

Callahan, E.H. 1986, A Thinking Man's Flintknapper: The Errett Callahan Story. Flintknapping Digest, 3(2): 4-11.

Callahan, E.H. 1987, Anatomy of Decision. In: Flintknapping: An Emic Perspective (Harwood, R.J., Atwood, E. \& Bailey, R., Eds.), Harwood Archaeology, Palmdale: p. 18-23.

Callahan, E.H. 1987, An Evaluation of the Lithic Technology in Middle Sweden During the Mesolithic and Neolithic. Aun, Archaeological Studies Vol. 8. Societas Archaeologica Upsaliensis, Uppsala, 72 p. 
Callahan, E.H. 1987, Flintknapping in Scandinavia. In: Flintknapping: An emic perspective (Harwood, R., Atwood, J.E. \& Bailey, R., Eds.), Harwood Archaeology, Palmdale.

Callahan, E.H. 1987, Metallic Powder as an Aid to Stone Tool Photography. American Antiquity, 52(4): 768-772. doi:10.2307/281384

Callahan, E.H. 1987, Piltdown Productions: Flint Replicas and Flintknapping Supplies (Catalogue). Piltdown Productions, Lynchburg, VA.

Callahan, E.H. 1987, Primitive Technology: Practical Guidelines for Making Stone Tools, Pottery, Basketry, etc. The Aboriginal Way (1st ed.). Piltdown Productions, Lynchburg, VA, $25 \mathrm{p}$.

Callahan, E.H. 1989, Dear D.C. Chips, 1(2): unpaginated letter inserted in newsletter.

Callahan, E.H. 1990, Bågskytte i Arktis. Forntida Teknik - Pilbågar, 90(2): 17-28. (in Swedish) ("Archery in the Arctic")

Callahan, E.H. 1990, Piltdown Productions Catalog \#4. Piltdown Productions, Lynchburg, VA.

Callahan, E.H. 1991, Arctic Archery. Bulletin of Primitive Technology, 1(Spring - The Founding Of The SPT): 35-38.

Callahan, E.H. 1991, Arctic Archery: Part II. Bulletin of Primitive Technology, 2(Fall): 47-54.

Callahan, E.H. 1991, Contrasting Viewpoints: Does dressing the part detract from Authenticity? Bulletin of Primitive Technology, 1(Spring - The Founding of the SPT): 5-6.

Callahan, E.H. 1991, The Making of Science (Heaven Forbid!). Bulletin of Primitive Technology, 2(Fall): 10-11.

Callahan, E.H. 1991, Out of Theory and into Reality: A Comment on Nami's Comment. Plains Anthropologist, 36(137): 367-368. doi:10.1080/2052546.1991.11909644

Callahan, E.H. 1991, The Society as Campfire; A Look At How We Got Started. Bulletin of Primitive Technology, 1(Spring - The Founding Of The SPT): 8-9.

Callahan, E.H. 1992, Flintknapping, Elitism, and Fracture Geometry: A Cautionary Note. Bulletin of Primitive Technology, 4(Fall - Projectile Technology): 16-19.

Callahan, E.H. 1992, The Non-Returning Boomerang. Bulletin of Primitive Technology, 4(Fall - Projectile Technology): 25-27.

Callahan, E.H. 1992, North American House Projects. Bulletin of Primitive Technology, 3(Spring - House Projects): 31-33.

Callahan, E.H. 1992, Tools and Materials. Bulletin of Primitive Technology, 3(Spring - House Projects): 25-26.

Callahan, E.H., Forsberg, L., Knutsson, K. \& Lindgren, C. 1992, Frakturbilder. Kulturhistoriska kommentarer till det säregna sönderfallet vid bearbetning av kvarts. Tor, 24: 27-63. (in Swedish) ("Fracture patterns; The cultural significance of the peculiar disintegration of quartz during processing") URL: https://www.researchgate.net/publication/284670266

Callahan, E.H. 1993, Celts at Pamunkey and Cahokia. Bulletin of Primitive Technology, 5(Spring - Stone Tools): 36-40. 
Callahan, E.H. 1993, Danish Neolithic Boat Project. Bulletin of Primitive Technology, 6(Fall Water Craft): 42-43.

Callahan, E.H. 1993, Experimentell arkeologi i USA idag. Forntida Teknik, 2: 24-27. (in Swedish) ("Experimental Archeology in the USA Today")

Callahan, E.H. 1993, Medicine Bow Wickiups. Bulletin of Primitive Technology, 5(Spring Stone Tools): 74-75.

Callahan, E.H. 1993, Processing Acorns. Bulletin of Primitive Technology, 6(Fall - Water Craft).

Callahan, E.H. 1993, Sword in the Stone Supplement to Our 1990 Catalog \#4. Piltdown Productions, Lynchburg, VA.

Callahan, E.H. 1994, The Holmegaard Bow: Fact \& Fiction. Bulletin of Primitive Technology, 8(Fall - At The Water's Edge): 52-58.

Callahan, E.H. 1994, A Mammoth Undertaking. Bulletin of Primitive Technology, 7(Spring Primitive Art): 23-39.

Callahan, E.H. 1994, Traditionalism vs. Modernism. Bulletin of Primitive Technology, 8(Fall - At The Water's Edge): 9.

Callahan, E.H. 1995, Appendix 2. Blades from Middle Neolithic Battle Axe Culture Graves in Sweden. In: Slutvandrat? Aspekter på övergången från rörlig till bofast tillvaro (Knuttson, H., Ed.), Societas Archaeologica Upsaliensis, Uppsala.

Callahan, E.H. (1995). The Cahokia Pit House Project: A Case Study in Reconstructive Archaeology.Unpublished manuscript, Flagstaff, Arizona.

Callahan, E.H. 1995, Flintknapping Flash Cards: Pressure Flaking of Flakes (5th ed.). Piltdown Productions, Lynchburg, 20 cards (double sided) p.

Callahan, E.H. 1995, Functional Motions. bulletin of Primitive Technology, 9(Spring - Music and Woodwork).

Callahan, E.H. 1995, A Memorial to JB Sollberger. Bulletin of Primitive Technology, 10(Fall - Bone, Tooth and Antler): 76-77, 95.

Callahan, E.H. 1995, An Ongoing Discussion. Bulletin of Primitive Technology, 10(Fall Bone, Tooth and Antler): 7-8.

Callahan, E.H. 1995, Sollberger Memorial. Bulletin of Primitive Technology, 10(Fall - Bone, Tooth and Antler): 76-77.

Callahan, E.H. 1995, To Whom it May Concern (Using Stone Tips). Bulletin of Primitive Technology, 10(Fall - Bone, Tooth and Antler): 80.

Callahan, E.H. 1995, Using Stone Tips. Bulletin of Primitive Technology, 10(Fall - Bone, Tooth and Antler).

Callahan, E.H. 1995, What is Experimental Archaeology. Newsletter of Primitive Technology, $1: 3-5$.

Callahan, E.H. 1996, The Bipolar Technique: The Simplest Way to Make Stone Tools for Survival. Bulletin of Primitive Technology, 12(Fall - Lower Paleo Tools): 16-20.

Callahan, E.H. 1996, In Defense of Level II. Primitive Technology Newsletter, 2(Fall): 8. 
Callahan, E.H. 1996, Oldowan, Abbevillian, Acheulean [from APE \#1]. Bulletin of Primitive Technology, 12(Fall - Lower Paleo Tools).

Callahan, E.H. 1996, Preface from 'The Basics of Biface Knapping in the Eastern Fluted Point Tradition: A Manual for Flintknappers and Lithic Analysts'. Bulletin of Primitive Technology, 11(Spring - Primitive Technology For Kids): 56-60.

Callahan, E.H. 1996, A review of Whitakker (1994): Flintknapping: making and understanding stone tools. Bulletin of Primitive Technology, 11(Spring - Primitive Technology For Kids): 82-85.

Callahan, E.H. 1996, A View From The Ridge . State of the Society - The First Five Years 1990-1995. Bulletin of Primitive Technology, 11(Spring - Primitive Technology For Kids): 8-9.

Callahan, E.H. 1997, Back to the Stone Age: How to Identify and Use the Best Stone Knives. Blade Magazine, 24(5): 16-19.

Callahan, E.H., Abbott, D. \& Viars, K. 1998, Problem solving in primitive ceramics: a three part experiment. Bulletin of Primitive Technology, 15(Spring - Ceramics): 26-33.

Callahan, E.H. 1999, About Animal Glues. In: Primitive Technology, a book of earth skills, selection of articles from the Bulletin of Primitive Technology (Wescott, D., Ed.), Society of Primitive Technology, Utah: p. 190.

Callahan, E.H. 1999, Excerpts from the Pamunkey project; Methodology and documentation. Bulletin of Primitive Technology, 18(Fall - House Building): 43-48.

Callahan, E.H. 1999, Functional Motions, working wood with stone tools. In: Primitive Technology, a book of earth skills, selection of articles from the Bulletin of Primitive Technology (Wescott, D., Ed.), Society of Primitive Technology, Utah: p. 116-118.

Callahan, E.H. 1999, How to make a Throwing Stick, The Non-Returning Boomerang. In: Primitive Technology, a book of earth skills, selection of articles from the Bulletin of Primitive Technology (Wescott, D., Ed.), Society of Primitive Technology, Utah: p. 214-217.

Callahan, E.H. 1999, Ishi sticks, Iceman picks and good-for-nothing things: a search for authenticity in pressure flaking tools. Bulletin of Primitive Technology, 18(Fall - House Building): 60-68.

Callahan, E.H. 1999, Piltdown Productions Catalog. Vol. 5. Piltdown Productions, Lynchburg, $72 \mathrm{p}$.

Callahan, E.H. 1999, Roving at Red House. In: Roving Handbook; An Alternative To Hunting (Callahan, E.H., Ed.), Piltdown Productions, Lynchburg: p. 99-107.

Callahan, E.H. (Ed.) 1999, Roving handbook; An alternative to hunting. Piltdown Productions, Lynchburg, VA, 128 p.

Callahan, E.H. 1999, Stages of Manufacture - percussion reduction. In: Primitive Technology, a book of earth skills, selection of articles from the Bulletin of Primitive Technology (Wescott, D., Ed.), Society of Primitive Technology, Utah: p. 78.

Callahan, E.H. 1999, To whom it may concern (endorsement for hunting with stone arrowpoints). In: Primitive Technology, a book of earth skills, selection of articles from the Bulletin of Primitive Technology (Wescott, D., Ed.), Society of Primitive Technology, Utah: p. 81. 
Callahan, E.H. 1999, What Is Experimental Archaeology. In: Primitive Technology, a book of earth skills, selection of articles from the Bulletin of Primitive Technology (Wescott, D., Ed.), Society of Primitive Technology, Utah: p. 4-6.

Callahan, E.H. 1999, A Word On Pitch. In: Primitive Technology, a book of earth skills, selection of articles from the Bulletin of Primitive Technology (Wescott, D., Ed.), Society of Primitive Technology, Utah: p. 190.

Callahan, E.H. \& Titmus, G. 1999, Flintknapper's syndrome: A caution to flintknappers. Bulletin of Primitive Technology, 17(Spring - Fibers): 66-70.

Callahan, E.H. 1999 Celts and Axes, Celts in the Pamunkey and Cahokia House building projects. In: Primitive Technology, a book of earth skills, selection of articles from the Bulletin of Primitive Technology (Wescott, D., Ed.), Society of Primitive Technology, Utah: p. 94-98.

Callahan, E.H. 2000, The basics of biface knapping in the Eastern Fluted Point Tradition: A manual for flintknappers and lithic analysts (4th ed.). Piltdown Productions, Lynchburg, 213 p. URL: http://www.thebasicsbycallahan.com/

Callahan, E.H. 2000, Experiments with Danish Mesolithic Microblade Technology. Bulletin of Primitive Technology, 20(Fall - Transportation): 62-68.

Callahan, E.H. 2000, Mastery: A Reconsideration of Standards. Bulletin of Primitive Technology, 20(Fall - Transportation): 9-10.

Callahan, E.H. 2000, Roving at Red House. Primitive Archer, 8(1): 13-17.

Callahan, E.H. 2000, What is Traditional Flintknapping? Bulletin of Primitive Technology, 20(Fall - Transportation): 11.

Callahan, E.H. 2001, Archaeological evidence of a Rotator Cuff injury. Bulletin of Primitive Technology, 21(Spring - Lithic Technology): 44-47.

Callahan, E.H. 2001, Archery In The Arctic - Part I. In: Primitive Technology II, Ancestral skills, from the Society of Primitive Technology (Wescott, D., Ed.), Society of Primitive Technology, Utah: p. 119-122.

Callahan, E.H. 2001, Archery In The Arctic - Part II. In: Primitive Technology II, Ancestral skills, from the Society of Primitive Technology (Wescott, D., Ed.), Society of Primitive Technology, Utah: p. 123-127.

Callahan, E.H. 2001, Archery In The Arctic - Part III. In: Primitive Technology II, Ancestral skills, from the Society of Primitive Technology (Wescott, D., Ed.), Society of Primitive Technology, Utah: p. 128-133.

Callahan, E.H. 2001, The Bipolar Technique: The Simplest Way To Make Stone Tools. In: Primitive Technology II, Ancestral skills, from the Society of Primitive Technology (Wescott, D., Ed.), Society of Primitive Technology, Utah: p. 217-220.

Callahan, E.H. 2001, A Burned Flint Experiment. Bulletin of Primitive Technology, 22(Fall Fire And Its Uses).

Callahan, E.H. 2001, Craft or Art? Bulletin of Primitive Technology, 22(Fall - Fire And Its Uses): 85-86.

Callahan, E.H. 2001, Danish Neolithic Boat Project. In: Primitive Technology II, Ancestral skills, from the Society of Primitive Technology (Wescott, D., Ed.), Society of Primitive Technology, Utah: p. 195-196. 
Callahan, E.H. 2001, How To Cook In Primitive Pottery. In: Primitive Technology II, Ancestral skills, from the Society of Primitive Technology (Wescott, D., Ed.), Society of Primitive Technology, Utah: p. 58-60.

Callahan, E.H. 2001, Regarding Bryon Rinehart. Bulletin of Primitive Technology, 22(Fall Fire And Its Uses): 5-6.

Callahan, E.H. 2001, Simple Comparative Tests Between Oldowan, Abbevillian and Acheulian Technology. In: Primitive Technology II, Ancestral skills, from the Society of Primitive Technology (Wescott, D., Ed.), Society of Primitive Technology, Utah: p. 225-227.

Callahan, E.H. 2002, Hans de Haas: the gentle giant. Bulletin of Primitive Technology, 23(Spring - International Projects): 27-28.

Callahan, E.H. 2002, The Pamunkey Indian Museum Displays. Bulletin of Primitive Technology, 23(Spring - International Projects).

Callahan, E.H. 2002, Silviculture. Bulletin of Primitive Technology, 24(Fall - Gifts From The Earth): 36-39.

Callahan, E.H. 2002, The Tsirk Challenge. Bulletin of Primitive Technology, 24(Fall : Gifts From The Earth).

Callahan, E.H. 2002, The Tuning of Atlatl Darts. Bulletin of Primitive Technology, 23(Spring - International Projects).

Callahan, E.H. 2003, Doug Waldorf, Living Legend: A Biographical Tribute. Knife Throwers. Accessed: 21 August 2019. URL: http://www.throwingknives.com/

Callahan, E.H. 2003, Escape To The Wilderness. Bulletin of Primitive Technology, 26(Fall Living with the Weather).

Callahan, E.H. 2003, A Pause For Thought: EXARC. Bulletin of Primitive Technology, 26(Fall - Living with the Weather).

Callahan, E.H. 2003, A tribute to Tomas Johansson. Bulletin of Primitive Technology, 26(Fall - Living with the Weather): 8.

Callahan, E.H. 2003, Update on Archeon. Bulletin of Primitive Technology, 26(Fall - Living with the Weather).

Callahan, E.H. 2004, Lejre Update, 2004. Bulletin of Primitive Technology, 28(Fall - Storage, Containers and Storable Foods).

Callahan, E.H. 2005, The Cahokia Project. A case study in reconstructive archeology. Society of Primitive Technology, Schiele Museum of Natural History, Rexburg, ID, 548 p.

Callahan, E.H. 2006, From - three levels of investment in reconstruction: therapy, experience and experiment. Bulletin of Primitive Technology, 32(Fall - Clothing): 11-12.

Callahan, E.H. 2006, Neolithic Danish daggers: An experimental peek. In: Skilled Production and Social Reproduction. Aspects on Traditional Stone Tool Technologies (Apel, J. \& Knutsson, K., Eds.), Uppsala University, Societas Archaeologica Upsaliensis (SAU) \& The Department of Archaeology and Ancient History, Uppsala: p. 115-129.

Callahan, E.H. 2007, The passing of a legend. Bulletin of Primitive Technology, 34(Fall Primitive Woodslore): 89-91. 
Callahan, E.H. 2008, Basic training: an opinion. Bulletin of Primitive Technology, 35(Spring Games and Amusements): 91.

Callahan, E.H. 2008, Old Rag Archeology: Experimentation and Excavation. Society of Primitive Technology Publications. Schiele Museum of Natural History, Rexburg, ID, $839 \mathrm{p}$.

Callahan, E.H. \& Zeak, T. 2009, Flintknapping Flash Cards: Pressure Flaking of Flakes (May 2009 ed.). Piltdown Productions, Lynchburg, 20 cards (double sided) p.

Callahan, E.H. 2010, Flake Removal Sequence and Cultural Inference. A Solutrean Perspective. In: Experiments and Interpretation of Traditional Technologies: Essays in Honor of Errett Callahan (Nami, H.G., Ed.), Ediciones de Arqueología Contemporánea, Buenos Aires: p. 561-659.

Callahan, E.H. 2011, Baskets and mats, folding \& plaiting, twining and coiling. Bulletin of Primitive Technology, 42(Fall): 76-77.

Callahan, E.H. 2011, Final Journey. The passing of Thorbjørn Petersen, a gentle giant. 4 July 1945 - 29 August 2010. Bulletin of Primitive Technology, 41(Spring): 91-92.

Callahan, E.H. 2011, Stages of Clovis biface reduction, revised. Bulletin of Primitive Technology, 42(Fall): 92.

Callahan, E.H. 2011, Surviving: skills or heart? Bulletin of Primitive Technology, 42(Fall): 85-86.

Callahan, E.H. \& Apel, J. 2011, The Flint Daggers of Denmanrk. Vol. 1 (1st ed.). Piltdown Productions, Lynchburg, 32 p.

Callahan, E.H. 2013, The basics of biface knapping in the Eastern Fluted Point Tradition: A manual for flintknappers and lithic analysts (5th ed.). Piltdown Productions, Lynchburg, 213 p. URL: http://www.thebasicsbycallahan.com/

Callahan, E.H. 2013, Fishing Technologies At The Pamunkey Site - Phase II. Bulletin of Primitive Technology, 46(Fall): 40-49.

Callahan, E.H. 2015, Experimental Methodology. Bulletin of Primitive Technology, 50(Fall From Theory To Practice): 27-37.

Callahan, E.H. 2015, Some suggested definitions. Bulletin of Primitive Technology, 50(Fall From Theory To Practice): 12.

Callahan, E.H. 2015, What Is Experimental Archeology? Bulletin of Primitive Technology, 50(Fall - From Theory To Practice).

Callahan, E.H. 2016, Neolithic Danish Daggers. Volume 2. A Manual for Flintknappers and Lithic Analysts. Piltdown Productions, Lynchburg, 314 p.

Callahan, E.H. 2019, Callahan Knives. Retrieved 21 August 2019.

URL: http://errettcallahan.com/knives

Callahan, E.H. 2019, Errett Callahan Home Page. Retrieved 21 August 2019.

URL: http://www.errettcallahan.com/ 


\section{Works about Errett Callahan}

Shackleford, S. 1987, Blades for the Present from Methods of the Past. Blade Magazine, 1987(Sept/Oct): 20-21, 50, 54-55.

Rutledge, D. 1989, Modern Day Artist Errett Callahan has much in Common with Ancient Stone Age People. Camera Press International.

Watts, S. 1997, The Fire Watchers: A tribute to Errett Callahan. Bulletin of Primitive Technology, 14(Fall).

West, K. 2007, Biography of Errett Callahan. Retrieved 21 August 2019. URL: http://errettcallahan.com/

Harwood, R. 2010, Errett Callahan Story. The Flintknapping Digest, 2010. Accessed: 21 August 2019. URL: https://flintknappingdigest.blogspot.com/2010/12/errett-callahanstory.html

Nami, H.G. (Ed.) 2010, Experiment and Interpretation of Traditional Technologies: Essays in Honor of Errett Callahan. Ediciones de Arqueología Contemporánea, Buenos Aires, $660 \mathrm{p}$.

Sidoroff, M.-L. 2010, The Ceramic Legacy of Errett Callahan. In: Experiment and Interpretation of Traditional Technologies: Essays in Honor of Errett Callahan (Nami, H.G., Ed.), Ediciones de Arqueología Contemporánea, Buenos Aires: p. 537-558.

West, K. 2010, Erret Callahan: A Biographical Overview. In: Experiment and Interpretation of Traditional Technologies: Essays in Honor of Errett Callahan (Nami, H.G., Ed.), Ediciones de Arqueología Contemporánea, Buenos Aires: p. 21-27.

Schindler, B. 2012, Interview: Dr Errett Callahan. EXARC Journal, 2012(3). Accessed: 21 August 2019. URL: https://exarc.net/ark:/88735/10239

Harwood, R. 2013, Errett Callahan, Hall Of Fame Flintknapper \# 7. Flintknapping Hall Of Fame, 7. Accessed: 21 August 2019.

URL: http://flintknappinghalloffame.blogspot.com/2013/01/errett-callahan-hall-offame.html

Harwood, R. 2016, Callahan's Brain. Flintknapping Magazine, 2016(March). Accessed: 21 August 2019. URL: https://flintknappingmag.blogspot.com/2016/04/flintknappingmagazine-march-2016.html

Harwood, R. 2016, Errett Callahan. Flintknapping Magazine, 2016(February). Accessed: 21 August 2019. URL: https://flintknappingmag.blogspot.com/2016/02/flintknappingmagazine-february-2016.html

anonymous, 2019, Errett Callahan. the Digital Archaeological Record, Center for Digital Antiquity, Arizona State University, Tempe, AZ. Retrieved 21 August 2019.

URL: https://core.tdar.org/browse/creators/54020/errett-callahan

anonymous 2019, Errett Callahan. Wikipedia. Retrieved 21 August 2019.

URL: https://en.wikipedia.org/wiki/Errett_Callahan

anonymous 2019, Obituary of Errett Hargrove Callahan Jr. Diuguid Funeral Service \& Crematory. Retrieved 21 August 2019.

URL: https://diuguidfuneralservice.com/tribute/details/137549/Errett-CallahanJr/obituary.html 
anonymous, 2019, Society of Primitive Technology Home Page. Society of Primitive Technology, Backtracks LLC, Rexburg, ID. Retrieved 21 August 2019. URL: http://primitive.org/

Buck, G., (director), 2019, Memories of Errett Callahan. Running time: $6 \mathrm{~min}, 21 \mathrm{sec}$. URL: https://www.youtube.com/watch? $=01 \mathrm{vt} 4 \mathrm{XxmDqY}$

Harwood, R. 2019, Dr. Errett Callahan. Flintknapping Magazine, 2019(Summer). Accessed: 21 August 2019. URL: https://flintknappingmag.blogspot.com/2019/08/dr-errettcallahan-flintknapping.html

Harwood, R. 2019, Dr. Errett Callahan Memorial. Flintknapping Magazine, 2019. Accessed: 21 August 2019. URL: https://flintknappingmag.blogspot.com/2019/08/dr-errettcallahan-memorial.html

Nami, H.G. 2019, Errett H. Callahan (1937-2019): Researcher, flintknapper, and artist. Journal of Lithic Studies, 6(1): 12 p. doi:10.2218/jls.4124 